\title{
LEGAL CHALLENGES OF THE DECISIONS OF ENERGY REGULATORY AUTHORITIES IN CERTAIN EU MEMBER STATES
}

\begin{abstract}
Purpose. Delivering energy policy requires appropriate decisions of competent bodies. Issuing the binding decisions refers to the key powers of energy regulatory authorities. However, there are different approaches to the understanding of the legal nature of such decisions. In particular, in Ukraine there is no single school of thought regarding the legal nature of utilities tariffs decisions. Therefore, it is important to study the experience of foreign countries (e. g., EU member states) on this matter in order to elaborate the future recommendations on the enhancement of Ukrainian legislation. This paper aims at exploring the legal nature of the decisions issued by the energy regulatory authorities in certain EU member states, and at separating the main types and defining the correlation of regulatory, normative and administrative decisions of an energy regulatory authority.

In order to achieve the main goal of this research, the following objectives should be reached: 1) to analyse the legal framework for the decision-making of energy regulatory authorities in certain EU member states; 2) to classify the types of decisions of an energy regulatory authority; 3) to define the correlation of regulatory, normative and administrative acts of an energy regulatory authority.

Methods. Comparative legal analysis will be among the main methods of this research while analysing the national legislative approaches to decisions of energy regulatory authorities in certain countries. Results. Constitutions and other legal acts of certain countries provide the legislative basis of the research. Case law of judicial bodies of analysed countries represents the empirical basis of the paper.

Conclusions. It is concluded that the scope of the decision-making powers of energy regulators in certain countries differs. Various decisions can be challenged in a different way. While the individual decision-making powers in many cases are subject to general administrative procedure acts, legal acts on energy regulatory authorities do not clearly specify the types of their regulatory acts. Considering the principle of legal certainty, it is recommended to separate the regulatory (legislative) and individual (administrative) acts of an energy regulator and to define the specific types of such decisions and their core features in the national legislation.
\end{abstract}

Key words: economic sectoral regulation, energy regulatory authority, energy regulatory decision making, regulatory decision-making, administrative acts. 


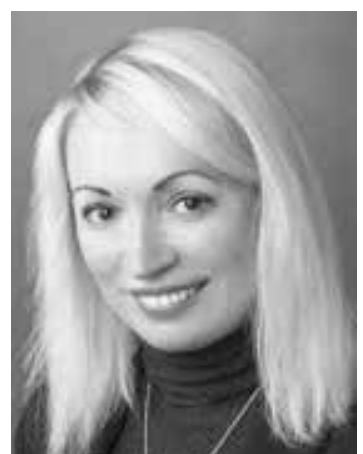

Yuliya Vashchenko,

Professor at the

Administrative Law

Department,

Faculty of Law, Taras

Shevchenko National

University of Kyiv,

Dr. Habil. (Law), Docent

y vashchenko@univ.kiev.ua

orcid.org/0000-0002-5252-1997

\section{Introduction}

Energy sector is one of strategic economic industries of each state. Sustainable, reliable, safe, accessible and affordable energy supply is crucial for the functioning of all other fields of economy. Access to modern energy services is essential condition for effective participation of the people in social and economic life, adequate realization of human rights and freedoms. Therefore, energy sector traditionally belongs to regulated industries in many countries in the world.

Efficiency of economic sectoral regulation in general and energy regulation in particular depends on adequate institutional encouragement. New approaches to the understanding of the role of a state in the field of economy as a regulator resulted in implementation of the model of independent national regulatory authorities. The trend of agencification, including the rise of the regulatory state in the energy sector, attracts the attention of scholars all over the world. Representatives of economic, political, legal, and other sciences explore different issues of this phenomenon (e. g., Majone, 1997; Christensen, 2005; Claeys, 2008; Deviatnikovaite, Bakaveckas, 2009; Helderman et al., 2012; Vasconcelos, 2009). The aspects of institutional, functional, and financial independence of regulatory authorities, as well as the correlation of independence and accountability of such authorities have been mostly discussed.

Issuing the binding decisions refers to the key powers of such authorities. However, such decisions have different legal nature and specific legal regulation arisen from the peculiarities of national legal systems. In particular, energy regulatory authorities can participate in the normative legal regulation of regulated industries via:

- approving the own regulations (legislative acts);

- participating in legislative procedures of other public authorities.

Considering that the quasi-legislative powers are among the key features of independent regulatory authorities, it is necessary to explore the legal nature of the acts of an energy regulatory authority.

Various decisions may cause different legal consequences and can be challenged in a different way. The issues referred to the legal nature of energy regulatory authorities was primarily explored by the author while analysing legal aspects of energy regulation in Ukraine and then the similar problems were found out in some other countries. Thus, it was realized that these aspects require more comprehensive legal research that has been done before. 
Considering mentioned above, this paper aims at exploring the legal nature of the decisions issued by the energy regulatory authorities, and at separating the main types and the core features of such decisions.

In order to achieve the main goal of this research, the following objectives should be reached:

1) to analyse the legal framework for the decision-making of energy regulatory authorities in certain EU member states;

2) to classify the types of decisions of an energy regulatory authority;

3) to separate the main features and to define the correlation of regulatory decisions, regulatory and administrative acts of an energy regulatory authority.

This research has been based on the theoretical approaches to the legal status of energy regulatory authorities represented in the modern science, in particular, mentioned above. Comparative legal analysis and case studies will be among the main methods of this research while analysing the national legislative approaches to decisions of energy regulatory authorities in certain countries. Constitutions and other legal acts of certain countries provide the legislative basis of the research. Case law of judicial bodies of analysed countries represents the empirical basis of the paper. The comparative legal analysis will be conducted primarily with regards to the following aspects: the constitutional basis for energy regulatory decision-making, the nature and the scope of the regulatory powers, the legal framework for regulatory decision-making, types and features of decisions of energy regulatory authorities. Due to the fact that the legal nature of the decisions of an energy regulatory authority depends on the legal status of the authority such criterion as the type of energy regulatory authority and its place in the system of public authorities will be also taken into consideration.

2. Legal framework for decision-making process of energy regulatory authorities in certain EU Member States

The EU legislation (in particular, Directive 2009/72/EC concerning common rules for the internal market in electricity (Directive 2009/72/EC, 2009) and Directive 2009/73/ EC concerning common rules for the internal market in natural gas (Directive 2009/73/ EC, 2009) includes certain requirements on regulatory decision-making, primarily, regarding its independence, impartiality, transparency, judicial review. The European Commission (The European Commission, 2010) encourages the EU Member States to fulfil these requirements while establishing the national institutional frameworks of energy regulation. However, the EU member states decide on concrete legal mechanisms regarding the energy regulatory decision-making process based on the peculiarities of their legal and political systems, and such solutions are different. For the purposes of this paper the approaches to the energy regulatory decisions used in Hungary, Lithuania, Poland, Latvia, Slovenia, and Netherlands have been analysed.

2.1. Energy regulatory decisions in Hungary

Hungarian Energy and Public Utility Regulatory Authority (HEA) is responsible for energy regulation in Hungary. This authority has a status of an autonomous regulatory body. HEA has a special constitutional footing - Article 23 of the Fundamental Law of Hungary (Fundamental Law of Hungary, 2011). The President of the HEA is appointed by the Prime Minister for seven years. Acting on the basis of authorization by an Act and 
within his or her functions laid down in a cardinal Act, the President shall issue decrees (legal regulations in accordance with Article T of the Fundamental Law of Hungary); no such decree shall conflict with any Act, government decree, prime ministerial decree, ministerial decree or decree of the Governor of the National Bank of Hungary. In issuing decrees, the President may be substituted for by the vice president he or she designated in a decree. Issues that shall be regulated by Presidential decrees defined by the Cardinal Act (para. 12) and acts on sectoral regulation. However, the list of issues that can be regulated by decrees is not exhaustive since in accordance with para. 12 of the Cardinal Act XXII (Cardinal Act, 2013) the President shall issue Organizational and Operational Rules and other decrees of the HEA. It is important to mention that the President issues not only legal regulations, but also administrative decisions (resolution adopted on the basis of authorization granted by law). Thus, the law should clear define the grounds for issuing decrees and resolutions. The procedural framework of individual administrative decisions is regulated by law, primarily the Act CL on General Public Administration Procedures (Act CL on General Public Administration Procedures, 2016).

There are different methods of judicial review of the decisions of HEA. Individual administrative decisions can be reviewed by courts. In accordance with Article XXVIII (7) of the Fundamental Law everyone shall have the right to seek legal remedy against any court, authority or other administrative decision which violates his or her rights or legitimate interests. As referred to in Article 25 of the Fundamental Law courts shall decide on the lawfulness of administrative decisions. Constitutionality of the President's decrees is examined by the Constitutional Court in accordance with Article 24 of the Fundamental Law.

\subsection{Decisions of the Lithuanian energy regulatory authority}

Energy regulation in Lithuania has been conducted by the National Commission for Energy Control and Prices (hereinafter - NCC). The legal status of the NCC is stipulated by the Law of Energy (Law on Energy, 2012). NCC is an independent national regulatory authority (in the European Union law's sense) regulating activities of entities in the field of energy and carrying out the supervision of state energy sector. Lithuanian legislation does not define the NCC as a body of executive power. First of all, Lithuanian Constitution (Article 5) (Constitution of the Republic of Lithuania, 1992) stipulates that in Lithuania, state power shall be executed by the Seimas, the President of the Republic and the Government, and the Judiciary. As referred to in Article 67 (para. 5) of the Lithuanian Constitution the Seimas shall establish state institutions provided for by law, and appoint and release their heads. It should be stressed that Lithuanian researchers define the NCC and other independent regulatory authorities in Lithuania as a part of the public administration, separated from the traditional hierarchy of the executive entities' system (Pūraitè, Deviantikovaitè, 2013).

According to the Law on Energy (2002) the NCC issues the regulations that are approved by the Chairperson of the Commission (Article 8, para. 14). As referred to in para. 12 of Article 8 of this Law the Commission shall be responsible for the validity and legitimacy of its resolutions.

In accordance with the Law on Public Administration (Law on Public Administration, 1999) (Article 2) the term "administrative decision" is a broadest term that means 
the administrative act or any other document of the established form adopted in accordance with the established procedure where the will of an entity of public administration is expressed. The Law separates administrative regulations (legal acts establishing the rules of conduct and intended for an individual and unspecified group of persons) and individual administrative act (an act of single application of law intended for a specific person or a specified group of persons).

NCC approves normative legal acts and individual legal acts. However, the Law on Energy while defining the responsibilities of the energy regulator does not strictly define when a normative or individual act should be approved. Types of legal acts to be approved by the NCC have not clearly defined, as well, since the Law on Energy mentions two terms - resolutions and regulations of the NCC. However, the difference between resolutions and the regulations is not defined.

\subsection{Decision-making powers of the Polish energy regulatory authority}

In Poland, the functions of the energy regulator performed by the President of the Energy Regulatory Office (hereinafter - ERO). According to the Energy Law Act (Energy Law Act, 1997) the President of the ERO is a central body of government administration that included to the system of bodies of executive power.

The President of ERO conducts different functions in the field of energy regulation, including sanctioning power. The procedures conducted by the President of the ERO are resulted in administrative acts. It is strictly defined by the Constitution of Poland and Energy Law Act that the President of the ERO can approve only administrative acts. Administrative decisions of the President of ERO approved in accordance with the Administrative Proceeding Code.

The President of ERO does not have legislative powers. The regulations in energy field (ordinances) approved by the bodies of executive power of higher level - President of the Council of Ministers, Council of Ministers and the Ministry of Energy. Internal organization and structure of the ERO is stipulated by the Statute of ERO approved by the ordinance of the President of the Council of Ministers (Art. 21, para.6).

2.4. Decision-making powers of the Latvian energy regulatory authority

Energy regulation in Latvia has been conducted by the Public Utilities Commission (hereinafter-PUC). In accordance with the Law on Regulators of Public Utilities (Law on Regulators of Public Utilities, 2000) PUC is institutionally and functionally independent, full-fledged, autonomous body governed by public law (Section 6(2)). It has a derived public person's status in accordance with the State Administration Structure Law (State Administration Structure Law, 2002).

It should be stressed that PUC has regulatory (even legislative) powers, however, such powers are not stipulated by the Constitution and the laws have different provisions on this matter. Thus, there are no special provisions on regulatory powers of the PUC in the Constitution of the Republic of Latvia (Satversme) (Constitution of the Republic of Latvia, 1998). Actually, the Constitution of Latvia does not define such types of public authorities as autonomous (independent) regulators. However, the Constitutional Court of the Republic of Latvia in its Judgement on Behalf of the Republic of Latvia in Case No. 2015-11-03 of 2 March 2016 (Judgement Constitutional Court of the Republic of Latvia in Case No. 2015-11-03, 2016) states that Article 57 of the Sarversme allows 
establishment of such autonomous state institutions, which perform some activities of executive power, without being subordinated to the Cabinet of Ministers.

In accordance with the Law on Regulators of Public Utilities the Regulator shall independently perform the functions delegated to it by law and, within the scope of its competence, shall take decisions independently and issue administrative acts binding upon specific providers and users of public utilities (Section 6(2)). The decision-making body of the Regulator shall be a Council. The Council shall, on behalf of the Regulator, take decisions and issue administrative acts binding upon specific providers and users of public utilities (Section 7 (3)). In accordance with the Law on Regulators of Public Utilities the Administrative Procedure Law (Administrative Procedure Law, 2001) applies to the administrative decision-making of the Regulator.

The provisions of the Administrative Procedure Law are also of particular interest in part of the regulatory powers of public authorities. In accordance with Section 1 (5) of this Law external regulatory enactments are comprised by the Constitution (Sarversme), laws, Cabinet regulations and binding regulations of local governments, as well as international agreements. The corresponding provision is stipulated in Section 15 (2), which prescribes that institutions and courts shall observe the following hierarchy of the legal force of external regulatory enactments: 1) the Constitution (Sarversme): 2) laws, and Cabinet regulations adopted in accordance with Article 81 of the Constitution (Satversme); 3) Cabinet regulations; 4) binding regulations of local governments. Therefore, one can assume that the Regulator cannot approve external regulatory enactments. However, in accordance with Section 9 (2) the Law of the Republic of Latvia on Official Publications and Legal Information external regulatory enactments, which have been issued by a derived legal person governed by public law in issues of the autonomous competence thereof (an autonomous public legal entity), shall be considered as equivalent to Cabinet regulation in the hierarchy of the legal force, unless specified otherwise by law (Law of the Republic of Latvia on Official Publications and Legal Information, 2012).

In 2016, the Constitutional Court of the Republic of Latvia in its Judgement on Behalf of the Republic of Latvia in Case No. 2015-11-03 of 2 March 2016 states that the Seima has the right to authorise an autonomous institution of public administration to issue external regulatory enactments that are necessary for implementing the law in a field of competence granted by law.

Therefore, the regulatory powers of the PUC are recognized; however, in order to avoid misunderstanding, it should be clearly specified in the legislation.

2.5. Decision-making powers of the energy regulatory authority in Slovenia

In Slovenia, the Energy Agency has a status of a bearer of public authorities. In accordance with the Energy Act, the Energy Agency is an independent body that does not belong to the system of bodies of executive power.

As referred to in Article 27 of the Public Agencies Act (Public Agencies Act, 2002) public agencies may, if by virtue of law granted such public authority, regulate legal relations and take decisions in individual matters. In the performance of tasks pursuant to paragraph 1 of this Article, public agencies shall issue general acts on exercising public authority, and administrative decisions. The general acts shall be adopted by the public agency Council. General acts of the Public Agency under the preceding paragraph are 
regulations published in the Official Gazette of the Republic of Slovenia. Public agencies shall be obliged to pass the general act under the preceding paragraph on to the founder in order for the act to be published. The founder may withhold the publication of a Public Agency general act, if the act is held to be in non-conformity with the constitution or law, and propose to the Public Agency to reconsider the adoption of the act in question; the founder shall state the reasons for withholding the publication. Where the Public Agency insists upon its decision, the general act shall be published; the founder may stay its implementation by filing with the Constitutional Court a request for review of constitutionality and legality of the general act, within 15 days after the act takes effect. The order of the founder staying the implementation of the general act pursuant to the preceding paragraph shall be published in the Official Gazette of the Republic of Slovenia.

Specific provisions of the Energy Agency are stipulated by the Energy Act (Energy Act, 2014). In accordance with Article 391 the Agency Council as a management body of the Agency shall, in particular, adopt general acts of the Agency in view of exercising public authority. As referred to in Article 408 of the Energy Act the Agency shall issue general acts in cases where it is authorized to do so by this Act or an EU Regulation. Administrative decisions of the Energy Agency are subject to the General Administrative Procedure Act (ZUP), unless special provisions are stipulated by the Energy Act (e.g., in Article 74(7), 82 (7) of the Energy Act).

The Slovenian experts point out that the procedure of issuing such acts of regulatory authorities is not as formalized with respect to its legislative regulation as is the case with other authorities, because these are mostly general acts issued by particular organizations whose activities are not as manifold as are those of the state administration, and they are not the representatives of different interests as reflected in the coalition structure of the Government, and are not the subject of political confrontation and discourse, which are the prime characteristics of legislative authorities (Čarni, Košak, 2006).

2.6. Decision-making powers of the energy regulatory authority in the Netherlands

Energy regulatory body in the Netherlands is the Authority for Consumers and Markets (ACM). ACM is an autonomous administrative authority (under Dutch law). Legal status of the ACM is stipulated, in particular, by the Autonomous Administrative Authorities Framework Act (Autonomous Administrative Authorities Framework Act, 2006) (hereinafter - Framework Act) and the Establishment Act of the Authority for Consumers and Markets (Establishment Act of the Authority for Consumers and Markets, 2013) (hereinafter - Establishment Act). In Section 1 of the Framework Act an autonomous administrative authority is defined as an autonomous administrative authority of central government which by Act of Parliament, by order in council pursuant to Act of Parliament, or by ministerial order pursuant to Act of Parliament, has been invested with public authority and is not hierarchically subordinate to a minister.

In accordance with Section 11 of the Framework Act an autonomous administrative authority adopts administrative regulations on the basis of a statutory regulation that require the approval of the Minister. Approval may be withheld on the grounds that the administrative regulations are incompatible with the law of that the Minister believes they may hinder the autonomous administrative authority in the proper performance of its tasks. 
Regulatory powers of the ACM are defined by the Establishment Act. Thus, according to Section 4 of this Law the ACM shall draw up regulations of the board. After the approval as referred to in Section 11 of the Framework Act, the ACM shall publish the regulations of the board in the Government Gazette.

The ACM enjoys the power to issue administrative decisions. According to Section 22 of the Framework Act the Minister may reverse a decision made by an autonomous administrative authority. A decision to do so must be announced in the Government Gazette. However, as referred to in Section 10 of the Establishment Act the Minister of Economic Affairs or the Minister of Infrastructure and the Environment cannot overturn decisions concerning energy that are taken by the ACM on the basis of provisions stated under or pursuant to an act that is valid for a specific market sector. Section 22, first paragraph of the Framework Act does not apply to these decisions. When drawing up and publishing decisions, ACM follows the rules of the Dutch General Administrative Law Act (Dutch General Administrative Law Act, 1994) (GALA).

It should be noticed that in Netherlands the broad concept of regulation has been used. Thus, a definition of regulation usually covers more than just the promulgation of (generally binding) rules. In the context of government policy and public services, regulation is normally considered to be the control of something by rules, as opposed to its prohibition. In this respect, regulation is not limited to rulemaking. It is also about licensing, inspection and enforcement, and sometimes even dispute resolution. In relation to market failure, regulation is normally the opposite of deregulation and liberalization. Regulation in this sense includes setting standards that determine the 'rules of the game' on markets for public services. As far as administrative law is concerned, regulation is in some countries narrowly termed as the legal restrictions promulgated by administrative agencies in contrast with statutory law or case law (Van Gestel et al., 2007).

It should be mentioned that in accordance with Article 1:3 of the GALA "administrative decision" means an order which is not of a general nature, including rejection of an application for such an order, whereas 'policy rule' means an order, not being a generally binding regulation, which lays down a general rule for weighing interests, determining facts or interpreting statutory regulations in the exercise of a power of an administrative authority.

As Dutch scholars pay attention, the GALA relates mainly to orders, specifically individual decisions. In the Netherlands there is a clear difference between constitutionally regulated decision-making processes at central government level, which result in primary legislation, "general administrative orders" (comparable to "orders in council" in the UK and "executive orders" in the US) and ministerial regulations on the one hand and administrative procedures on the other hand, which usually result in individual decisions (beschikkingen) (Barkhuysen et al., 2012).

\section{Conclusions}

Issuing the regulatory decisions belongs to essential powers of an energy regulatory authority in certain EU member states. However, there are different approaches to the understanding of the legal nature and the scope of regulatory powers and regulatory decisions. Thus, the broad and the narrow approaches can be defined. In accordance with broad approach (e. g., used in Slovenia and Netherlands), the regulatory powers include the whole range of powers of energy regulatory authority, including issuing the legally 
binding rules and decisions, licensing, control etc. In this case regulatory decisions cover both legislative (normative) and individual (administrative) decisions. Pursuant to narrow approach, regulatory powers mean only legislative (normative) regulation.

However, there are also broad and narrow approaches to the understanding of the term "administrative decisions" ("administrative acts"). In accordance with the broad approach, administrative decisions include also normative acts approved by public administration entities (e. g., in Lithuania). And pursuant to the narrow approach administrative decisions cover only individual acts.

Therefore, considering the importance of unified use of the most significant terms, it is recommended to understand under regulatory powers of energy regulatory authorities the whole range of their powers. In this case, the term "regulatory decision" will apply to all decisions of the energy regulatory authorities refer to their regulatory powers. It can play the role of an umbrella term for legislative and administrative decisions of a regulatory authority. Following this approach, the legislative (normative) act can be covered by the term "regulatory act"/ "regulatory rule", whereas the term "administrative act" will mean the individual act of an energy regulatory authority.

The scope of regulatory powers of an energy regulatory authority depends on the legal status of such authority and it place in the system of public administration. All regulatory authorities are vested with administrative powers resulted in administrative acts, whereas the legislative powers mostly refer to the responsibilities of independent energy regulators (e. g., in Lithuania and Latvia). Energy regulators that belong to the system bodies of executive power may lack legislative (regulatory) powers (e. g., in Poland).

Based on the analysis conducted, the legal regulation of legislative powers of energy regulatory authorities in the majority of certain countries needs to be enhanced. Considering the special status of independent energy regulatory authorities, their legislative powers shall be clearly defined in (or arisen from) the Constitution. The legal forms and the legal grounds of regulatory acts should be defined by law.

In all countries analysed in this research the administrative decision-making of the energy regulatory authorities is subject to general administrative procedure act that seems to be logically and legally proven. However, legislative and administrative acts of an energy regulatory authority should be clearly separated by law.

The enhancement of the energy regulatory decision-making in part of the clear legal regulation of legislative and administrative acts will contribute to the protection of interests of different stakeholders, primarily, energy consumers, and will increase the efficiency of general energy policy.

Bibliography:

1. Majone G. From the Positive to the Regulatory State: Causes and Consequences of Changes in the Mode of Governance. Journal of Public Policy. 1997. Vol. 17. P. 139-167. URL: http://www.jstor.org/stable/4007608?seq=1\#page_scan_tab_contents/(accessed 29 April 2018).

2. Christensen T. Agencification and regulatory reforms. URL: http://soc.kuleuven.be/io/ cost/pub/paper/AgencificationRegulatioryReforms_Final21021.pdf (accessed 29 April 2018).

3. Claeys E.R. The National Regulatory State in Progressive Political theory and Twentieth-Century Constitutional Law. George Mason Law \& Economics Research Paper. 2008. No. 08(44). URL: http://papers.ssrn.com/sol3/papers.cfm?abstract_id=1169870 (accessed 29 April 2018). 
4. Deviatnikovaite I., Bakaveckas A. Independent Regulatory Agencies: Possibilities to Identify the Peculiarities of Their Activity and Their Position in the System of Lithuanian Public Administration Bodies. Societal Studies. 2009. No. 3(3). P. 333-349. URL: https://www.mruni. eu/upload/iblock/15e/deviatnikovaite,\%20bakaveckas.pdf (accessed 29 April 2018).

5. Helderman J.-K., Bevan G., France G. The rise of the regulatory state in health care: a comparative analysis of the Netherlands, England and Italy. Health Economics, Policy and Law. 2012. No. 7. P. 103-124. URL: http://eprints.lse.ac.uk/41977/1/Bevan_Rise_regulatory_state_2012.pdf (accessed 29 April 2018).

6. Vasconcelos J. Energy regulation in Europe: regulatory policies and politics of regulation. URL: https://www.eeinstitute.org/european-review-of-energy-market/EREM_9-_Comment_ Jorge Vasconcelos.pdf (accessed 29 April 2018).

7. Directive 2009/72/EC of the European Parliament and the Council of 13 July 2009 concerning common rules for the internal market in electricity and repealing Directive 2003/54/EC. OJ. 2009. L211/55.

8. Directive 2009/73/EC of the European Parliament and the Council of 13 July 2009 concerning common rules for the internal market in natural gas and repealing Directive 2003/55/EC. OJ. 2009. L211/94.

9. Commission Staff Working Paper. Interpretative Note on Directive 2009/72/EC concerning common rules for the internal market in electricity and Directive 2009/73/EC concerning common rules for the internal market in natural gas (Brussels, 22 January 2010). URL: https:// ec.europa.eu/energy/sites/ener/files/documents/2010_01_21_the_regulatory_authorities.pdf (accessed 29 April 2018).

10. Fundamental Law of Hungary. URL: http://www.kormany.hu/download/e/02/00000/ The \%20New\%20Fundamental\%20Law\%20of\%20Hungary.pdf (accessed 6 April 2018).

11. Cardinal Act XXII of 2013 on the Hungarian Energy and Public Utility Regulatory Authority. URL: http://www.mekh.hu/download/c/1b/10000/act_xxii_of_2013_on_the_hungarian_ energy_and_public_utility_regulatory_authority.pdf (accessed 29 April 2018).

12. Act CL on General Public Administration Procedures (2016). URL: https://net.jogtar.hu/ $\mathrm{jr} /$ gen/getdoc.cgi?docid=a1600150.tv\&dbnum=62 (accessed 29 April 2018).

13. Law on Energy of 16 May 2002 No IX-884 (New version of the Law of 01 January 2012). Official Gazette. 2011. No 160(7576). URL: https://e-seimas.lrs.lt/portal/legalAct/lt/TAD/ cc700b403c3f11e68f278e2f1841c088?jfwid=-19kda1ip8y (accessed 30 March 2018).

14. The Constitution of the Republic of Lithuania (adopted by the citizens of the Republic of Lithuania in the Referendum of 25 October 1992). URL: http://www3.lrs.lt/home/Konstitucija/ Constitution.htm (accessed 30 March 2018).

15. Pūraitè A., Deviantikovaite I. Independent regulatory and administrative authorities in the Republic of Lithuania. TLQ. 2013. No. 4. P. 283-295. URL: https://tlq.ilaw.cas.cz/index.php/tlq/ article/view/99 (accessed 29 April 2018).

16. Energy Law Act (1997) / Ustawa z dnia 10 kwietnia 1997 r. Prawo energetyczne. URL: https://www.ure.gov.pl/pl/prawo/ustawy/17,Ustawa-z-dnia-10-kwietnia-1997-r-Prawo-energetyczne.html (accessed 1 April 2018).

17. Law on Regulators of Public Utilities of the Republic of Latvia (2000). URL: http://www. vvc.gov.lv/export/sites/default/docs/LRTA/Citi/On_Regulators_of_Public_Utilities.pdf (accessed 05.04.2018)

18. State Administration Structure Law of the Republic of Latvia (2002). URL: https://www. mk.gov.lv/sites/default/files/editor/state_administration_structure_law.pdf (accessed 5 April 2018).

19. Constitution of the Republic of Latvia (1998). URL: http://www.saeima.lv/en/legislation/ constitution (accessed 5 April 2018). 
20. Judgement on Behalf of the Republic of Latvia in Case No. 2015-11-03 of 2 March 2016. URL: http://www.satv.tiesa.gov.lv/wp-content/uploads/2015/04/2015-11-03_Spriedums_ENG. pdf (accessed 05 April 2018).

21. Administrative Procedure Law of the Republic of Latvia (2001). URL: https://likumi.lv/ ta/en/id/55567-administrative-procedure-law.

22. Law of the Republic of Latvia on Official Publications and Legal Information from 31 May 2012. URL: http://www.vvc.gov.lv/ (accessed 5 April 2018).

23. Public Agencies Act of the Republic of Slovenia No. 020-05/00-21/4 of 31 May 2002. URL: http://www.akos-rs.si/files/APEK_eng/Legislation/public-agencies-act.pdf (accessed 05 April 2018).

24. Energy Act of the Republic of Slovenia of 24 February 2014 (third reading version). URL: http://www.energetika-portal.si/fileadmin/dokumenti/zakonodaja/energetika/ez-1/ez-1_energy_ act_proposal.pdf (accessed 5 April 2018).

25. Čarni M., Košak Š. A Guide to the Republic of Slovenia Legal System and Legal Research. URL: http://www.nyulawglobal.org/globalex/Slovenia.html\#_3.2.1._Bearers_of_public\%20authoritie (accessed 05 April 2018).

26. Autonomous Administrative Authorities Framework Act of 2 November 2006. URL: https://www.cbs.nl/-/media/_pdf/2018/13/engelse\%20vertaling\%20kaderwet\%20zbos\%20\%20 autonomous\%20administrative\%20authorities\%20framework\%20act.pdf?la=en-gb (accessed 5 April 2018).

27. Establishment Act of the Authority for Consumers and Markets of February 28, 2013. URL: https://www.acm.nl/sites/default/files/old_publication/publicaties/13190_establishment-act-of-the-netherlands-authority-for-consumers-and-markets.pdf (accessed 5 April 2018).

28. Dutch General Administrative Law Act (1994). URL: https://www.acm.nl/sites/default/ files/old_publication/publicaties/15446_dutch-general-administrative-law-act.pdf (accessed 5 April 2018).

29. Van Gestel R.A.J., Eijlander Ph., Peters J.A.F. The Regulatory Powers of Quangos in the Netherlands: Are Trojan Horses Invading Our Democracy? Electronic Journal of Comparative Law. 2007. Vol. 11.1. URL: https://www.ejcl.org/111/art111-9.pdf (accessed 5 April 2018).

30. Barkhuysen T., Willemien Ouden W., Schuurmans Y. E. The Law on Administrative Procedures in the Netherlands. NALL. 2012. April-Juni. DOI: 10.5553/NALL/.000005. URL: http:// www.nall.nl/tijdschrift/nall/2012/06/NALL-D-12-00004.pdf (accessed 5 April 2018).

\section{ПРАВОВІ ПРОБЛЕМИ РІШЕНЬ ОРГАНІВ РЕГУЛЮВАННЯ ЕНЕРГЕТИКИ В ПЕВНИХ ДЕРЖАВАХ - ЧЛЕНАХ ЄВРОПЕЙСЬКОГО СОЮЗУ}

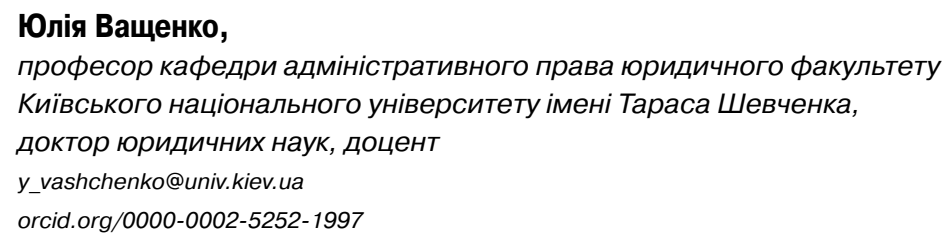

Мета. Реалізачія енергетичної політики вимагає належних рімень уповноважених органів. Прийняття обов'язкових до виконання рімень $\epsilon$ одним із ключових повноважень органів регулювання енергетики. Однак є різні підходи до розуміння 
правової природи таких рішень. Наприклад, в Україні немає єдиного підходу до розуміння правової природи рімень щодо тарифів на комунальні послуги. У зв'язку із иим важливо проаналізувати досвід зарубіжних країн (наприклад, держав членів Європейського Союзу) із иъього питання з метою подальшого розроблення рекомендацій щуоо вдосконалення законодавства України. Статтю присвячено з'ясуванню правової природи рімень органів регулювання енергетики у визначених державах-членах Свропейського Союзу, виокремленню основних видів та визначенню співвідношення між регуляторними, нормативними й адміністративними актами органу енергетичного регулювання.

Для досягнення поставленої мети необхідно виконати такі завдання: 1) проаналізувати правові засади прийняття рішень органами регулювання енергетики увизначених державах - членах Європейського Союзу; 2) надати класифікацію рімень органу регулювання енергетики; 3) визначити співвідношення між регуляторними, нормативними та адміністративними актами органу енергетичного регулювання.

Методи. Порівняльно-правовий метод $\epsilon$ одним 3 основних методів иъього дослідження та застосовується в прочесі аналізу національних законодавчих підходів до рімень органів регулювання енергетики у визначених краӥнах. Нормативну основу дослідження складають конституиії та інші законодавчі акти зазначених краӥн. Емпіричною основою дослідження є практика судових органів країн, щуо аналізуються.

Результати. 3'ясовано, щуо є широкий і вузький підходи до розуміння регуляторних повноважень органів регулювання енергетики. Відповідно до широкого підходу регуляторні повноваження включають увесь обсяг повноважень органу регулювання енергетики, тоді як до вузького належать лише повноваження з нормативноправового регулювання.

Обсяг повноважень органів регулювання енергетики в різних країнах відрізняється. Різні рішення мають різні правові наслідки таможуть бути оскаржені врізний спосіб. Натомість прийняття рішень індивідуальної дї в більшості випадків здійснюється відповідно до законів про загальну адміністративну прочедуру, а законодавчі акти, які закріплюють правовий статус органів регулювання енергетики, не завжди чітко визначають види їхніх регуляторних актів.

Висновки. Під регуляторними повноваженнями органів регулювання енергетики рекомендується розуміти повний обсяг їхніх повноважень. Відповідно, термін «регуляторне рішення» має застосовуватися до всіх рішень органів регулювання енергетики, прийнятих у межах їхніх регуляторних повноважень. При иьому категорія "регуляторний акт»/ «регуляторна норма» має застосовуватися саме до нормативно-правових актів, тоді як термін «адміністративний акт» - до актів індивідуальної дії.

3 огляду на принци правової визначеності рекомендується чітко розмежовувати регуляторні (нормативно-правові) та індивідуальні (адміністративні) акти органу регулювання енергетики, а також визначити види таких рішень та їхні ключові ознаки в національному законодавстві.

Ключові слова: економічне галузеве регулювання, орган регулювання енергетики, прийняття регуляторних рішень в енергетиці, прийняття регуляторних рішень, адміністративні акти. 